\title{
GMR
}

\section{Quercetin ameliorates LPS-induced inflammation in human peripheral blood mononuclear cells by inhibition of the TLR2-NF-kB pathway}

\author{
M. Zhang, J.M. Lin, X.S. Li and J. Li \\ Department of Microbiology and Immunology, Guangdong Medical College, \\ Dongguan, Guangdong, China \\ Corresponding author: M. Zhang \\ E-mail: mzhangiou@163.com
}

Genet. Mol. Res. 15 (2): gmr.15028297

Received December 16, 2015

Accepted February 1, 2016

Published July 15, 2016

DOI http://dx.doi.org/10.4238/gmr.15028297

\begin{abstract}
Quercetin, a dietary flavonoid abundant in fruits, vegetables, and herbs, presents various pharmacological effects. This study aimed to investigate the anti-inflammatory effect and the underlying mechanism of quercetin in lipopolysaccharide (LPS)stimulated human peripheral blood mononuclear cells (PBMCs). Cell viability was measured by the Cell Counting Kit-8 assay. The mRNA expression of Toll-like receptor 2 (TLR2) was assessed by quantitative real-time polymerase chain reaction. Inflammatory cytokine secretions and nuclear factor (NF)- $\kappa \mathrm{B}$ levels were analyzed by enzyme-linked immunosorbent assay. Our findings showed that quercetin significantly reduced LPS-induced cytotoxicity in human PBMCs. Quercetin suppressed the secretion of tumor necrosis factor- $\alpha$, interleukin (IL)$1 \beta$, and IL-6 in LPS-stimulated human PBMCs. Moreover, quercetin reduced the LPS-induced increase in the expression of TLR2 mRNA and decreased the NF- $\kappa B$ concentration in LPS-stimulated human PBMCs. The data indicates that quercetin plays an important role in
\end{abstract}


LPS-induced inflammation in human PBMCs via suppression of the TLR2-NF-кB pathway.

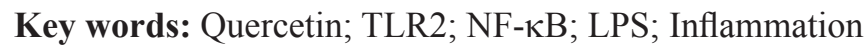

\section{INTRODUCTION}

There is an increasing evidence that the innate immune system is important in initiating the inflammatory cascade. Toll-like receptors (TLRs) play a key role in the recognition of exogenous pathogen-associated molecular patterns during the pathogenesis of sepsis, inflammatory bowel disease, adult respiratory distress syndrome (ARDS), and other local or systemic inflammatory disorders (Cohen, 2002; Jiang et al., 2005, Strober et al., 2007). TLRs are a family of type- 1 trans-membrane receptors that emerge as key receptors of the innate immune system (Pestka and Zhou, 2006). The TLR family is composed of 10 members (TLR1-TLR10) in humans and 12 members (TLR1-TLR9, TLR11-TLR13) in mice (Akira, 2006). Among the mammalian TLR family, TLR2 has received particular attention because it is involved in the signaling pathway of the lipopolysaccharide (LPS) receptor complex (Werts et al., 2001). LPS, a component of the Gram-negative bacterial cell wall, induces inflammatory responses and leads to the disturbance of immune system function (Guha and Mackman, 2001). Moreover, previous studies reported that LPS significantly elevated the expression of inflammatory cytokines including tumor necrosis factor (TNF)- $\alpha$, interleukin (IL)-1 $\beta$, and IL-6 in normal rat kidney epithelial cells (Li et al., 2015) and activated the TLR2/ nuclear factor (NF)- $\mathrm{kB}$ signaling pathway following LPS-induced acute lung injury in mice (Tianzhu and Shumin, 2015) and rats (Zhu et al., 2016). Activation of TLR2 signaling can lead to NF- $\mathrm{kB}$ translocation, which induces inflammatory cytokine expression (May and Ghosh, 1998). Taken together, these results reveal that the TLR2-NF- $\mathrm{KB}$ signaling pathway plays an important role in LPS-induced inflammation.

Quercetin, one of the polyphenolic flavonoids, has been found in red grapes, red wine, tea, apples, citrus fruits, cherries, broccoli, and other leafy green vegetables. Quercetin presents various pharmacological effects, such as antioxidative (Gomes et al., 2014; Yang et al., 2014), anti-inflammatory (Morikawa et al., 2003), antidiabetic (Vessal et al., 2003), and antiobesity effects (Ahn et al., 2008). Quercetin was reported to inhibit the activation of NF$\kappa \mathrm{B}$ and p38 mitogen-activated protein kinase in calcium ionophore A23187-stimulated human mast cell line HMC-1 cells (Min et al., 2007). Previous studies demonstrated that quercetin could ameliorate inflammation induced by LPS (Angeloni and Hrelia, 2012; Yu et al., 2013; Takashima et al., 2014). However, the molecular mechanism of the anti-inflammatory effect of quercetin is still poorly understood. Here, we focus on the effect of the flavonoid quercetin on the mRNA expression of TLR2 and NF- $\mathrm{KB}$ activation in LPS-stimulated human peripheral blood mononuclear cells (PBMCs).

\section{MATERIAL AND METHODS}

\section{Materials and reagents}

Quercetin and LPS were purchased from Sigma (St. Louis, MO, USA). ELISA kits for NF- $\mathrm{BB}, \mathrm{TNF}-\alpha$, IL-1 $\beta$, and IL-6 were obtained from Shanghai Westang Biotechnology 
Co., Ltd. (Shanghai, China). The Cell Counting Kit-8 (CCK-8) was purchased from Shanghai Beyotime Biotechnology Co., Ltd. (Shanghai, P. R. China). Trizol regent was obtained from Invitrogen (Carlsbad, CA, USA) and DNase I was from Promega (Madison, WI, USA). Reverse transcriptase Moloney murine leukemia virus and QuantiTect SYBR Green real-time PCR kits were purchased from Toyobo Co., Ltd. (Osaka, Japan).

\section{PBMC isolation}

PBMCs were isolated from the peripheral blood of healthy human volunteers as described previously (Jenny et al., 2011) and collected in heparinized tubes. Separation of human PBMCs was performed using density centrifugation with Lymphoprep (Fresenius Kabi Norge AS, Oslo, Norway) (Dijkstra et al., 2007). Isolation was carried out under sterile conditions to prevent monocyte activation.

\section{Cell culture and treatments}

The isolated human PBMCs $\left(1 \times 10^{8} / \mathrm{mL}\right)$ were resuspended in RPMI 1640 medium and seeded onto flat-bottom plates overnight $\left(37^{\circ} \mathrm{C}, 5 \% \mathrm{CO}_{2}\right.$, humidified atmosphere). Then, these were divided into five different groups. Group I was the normal control group and Group II was treated with $10 \mu \mathrm{g} / \mathrm{mL}$ LPS as a model group. Groups III, IV, and V were pre-treated with $10 \mu \mathrm{g} / \mathrm{mL}$ LPS for $1 \mathrm{~h}$ and then 25,50 , and $100 \mu \mathrm{M}$ quercetin, respectively, were added and cells were maintained in culture for $24 \mathrm{~h}\left(37^{\circ} \mathrm{C}, 5 \% \mathrm{CO}_{2}\right.$, humidified atmosphere).

\section{Human PBMC viability assay}

After incubation of human PBMCs, cell viability was evaluated using CCK-8 according to the manufacturer recommendation and was measured colorimetrically on a microplate reader (Thermo Fisher Scientific, Waltham, MA, USA) at $450 \mathrm{~nm}$.

\section{ELISA}

After centrifugation $\left(10 \mathrm{~min}\right.$ at $\left.25^{\circ} \mathrm{C}\right)$, the human $\mathrm{PBMC}$ culture supernatants were harvested, protein was extracted from the supernatants of monocytes, and protein concentrations were determined using the bicinchoninic acid protein assay kit (Thermo Fisher, Waltham, MA, USA). The concentrations of NF- $\kappa$ B, TNF- $\alpha$, IL- 6 , and IL- $1 \beta$ were then determined by commercial ELISA kits following the manufacturer instructions. NF- $\kappa \mathrm{B}, \mathrm{TNF}-\alpha$, IL-6, and IL-1 $\beta$ concentrations are expressed as $\mathrm{pg} / \mathrm{mL}$.

\section{Quantitative RT-PCR}

Total RNA was isolated from human PBMCs using the total RNA isolation system according to the manufacturer recommendations. The purities and concentrations of the RNA were determined with a spectrophotometer. RNA reverse transcription was performed using PCR primers. The expression of TLR2 mRNA in the normal control, model, and quercetin-treated groups was detected by qRT-PCR according to the manufacturer instructions. The primers for TLR2 and 18s RNA were as follows: TLR2 (221 bp) (F: 5'-ACTTCTCCCATTTCCGTCTT-3'; 
R: 5'-GGACTTTATCGCAGCTCTCA-3'); for 18s RNA (162 bp) (F: 5'CCTGGATACCGCAGCTAGGA-3'; R: 5'-GCGGCGCAATACGAATGCCCC-3'). For mRNA quantification, the Fast Start Universal SYBR-Green Master mix (Roche Applied Science, Mannheim, Germany) was used. The reaction conditions for PCR were $5 \mathrm{~min}$ at $95^{\circ} \mathrm{C}$ followed by 40 cycles of $15 \mathrm{~s}$ at $95^{\circ} \mathrm{C}, 15 \mathrm{~s}$ at $60^{\circ} \mathrm{C}$, and $32 \mathrm{~s}$ at $72^{\circ} \mathrm{C}$. The specificity of the amplification was confirmed using a melting curve analysis. Relative expression values were expressed by normalizing to the expression of 18s RNA. The size of the PCR products was confirmed by agarose gel electrophoresis.

\section{Statistical analysis}

All data are reported as means \pm SD. Statistical analysis was performed with SPSS version 12.0 for Windows (SPSS, Chicago, IL, USA). Statistical differences between groups were determined using one-way analysis of variance followed by a post hoc test (Fisher's least significant difference test) when appropriate. A value of $\mathrm{P}<0.05$ was considered statistically significant.

\section{RESULTS}

\section{Quercetin reduces LPS-induced cytotoxicity in human PBMCs}

To examine the effect of quercetin on human PBMC viability in vitro, LPS was used to simulate inflammatory conditions in the cell cultures. As shown in Figure 1, LPS significantly inhibited cell viability compared with the normal control group $(\mathrm{P}<0.01)$, showing obvious cytotoxicity in human PBMCs. However, treatment with quercetin $(25 \mu \mathrm{M}: \mathrm{P}<0.05 ; 50$ and $100 \mu \mathrm{M}: \mathrm{P}<0.01)$ greatly increased human PBMC viability, almost reaching the normal level.

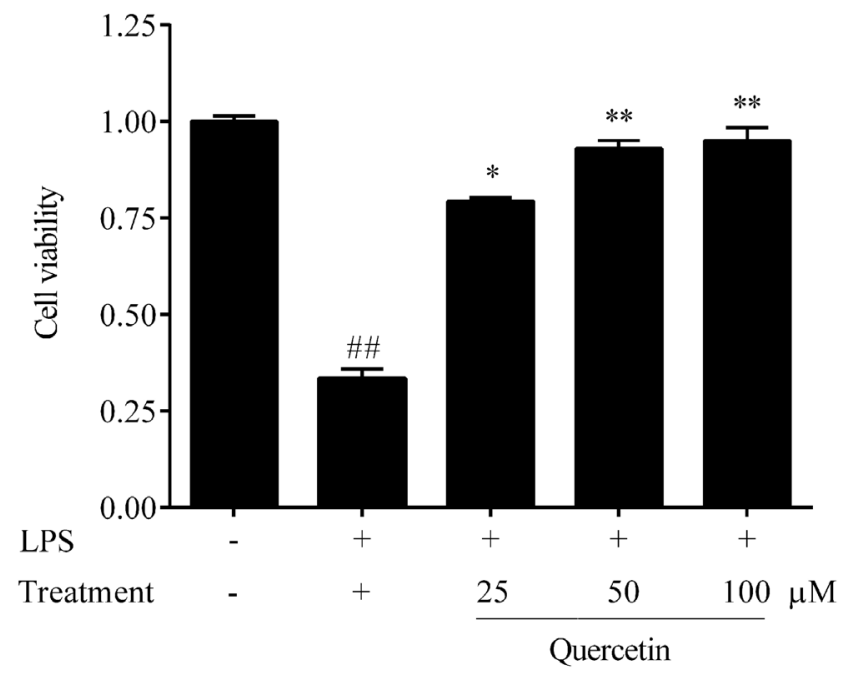

Figure 1. Effects of quercetin treatment on the viability of LPS-stimulated human PBMCs. Data are reported as means $\pm \mathrm{SD}(\mathrm{N}=3) .{ }^{\#} \mathrm{P}<0.01$, compared with normal control group; $* \mathrm{P}<0.05,{ }^{*} * \mathrm{P}<0.01$ compared with model group. 


\section{Quercetin suppresses LPS-induced over-secretion of TNF- $\alpha$, IL-1 $\beta$, and IL-6 in human PBMCs}

To determine the effect of quercetin on LPS-induced inflammation, we measured the secretion of inflammatory cytokines in human PBMCs. Elevated TNF- $\alpha(\mathrm{P}<0.01$; Figure 2A), IL-1 $\beta(\mathrm{P}<0.05$; Figure $2 \mathrm{~B})$, and IL-6 $(\mathrm{P}<0.01$; Figure $2 \mathrm{C})$ concentrations were observed in human PBMCs compared to that in the normal control group. Simultaneously, these alterations in LPS-stimulated human PBMCs were restored by the treatment with quercetin. As shown in Figure 2, quercetin treatment at all dosages significantly decreased the concentrations of TNF- $\alpha(25,50$, and $100 \mu \mathrm{M}: \mathrm{P}<0.05)$, IL-1 $\beta(25,50$, and $100 \mu \mathrm{M}: \mathrm{P}<0.05)$, and IL-6 (25 $\mu \mathrm{M}: \mathrm{P}<0.05 ; 50$ and $100 \mu \mathrm{M}: \mathrm{P}<0.01)$ in LPS-stimulated human PBMCs.

A

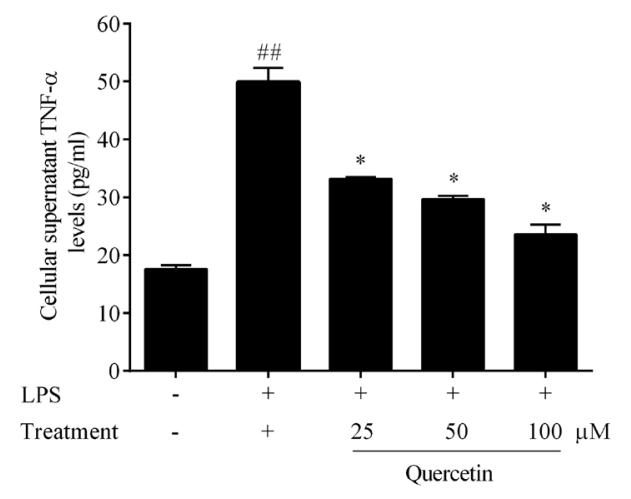

C

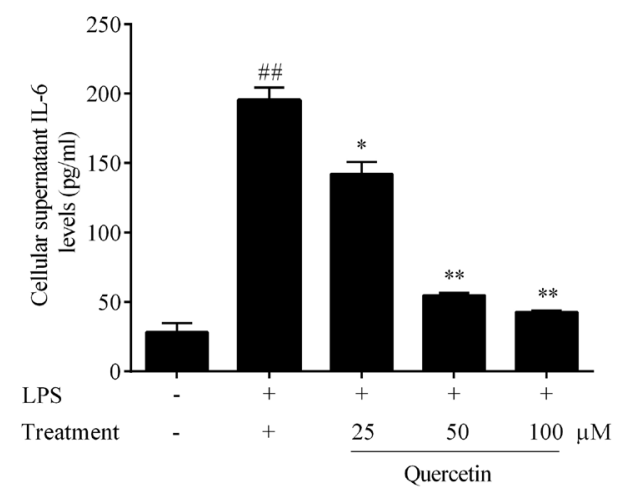

B

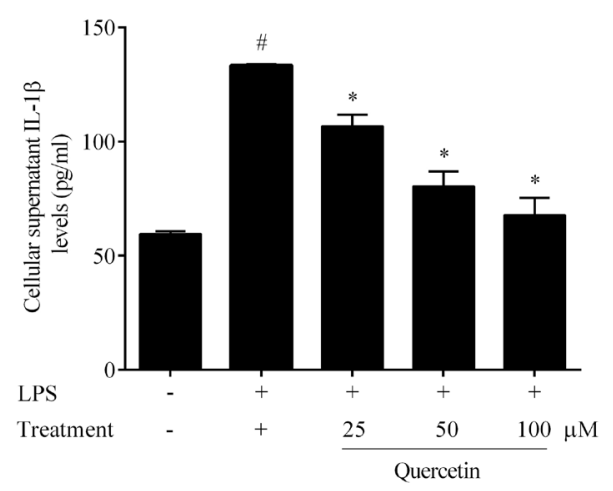

Figure 2. Effects of quercetin on inflammatory cytokine secretion in LPS-stimulated human PBMCs. Cellular supernatant TNF- $\alpha$ (A), IL-1 $\beta$ (B), and IL-6 (C) levels were measured by commercial ELISA kits, respectively. Data are reported as means $\pm \mathrm{SD}(\mathrm{N}=3)$. ${ }^{\#} \mathrm{P}<0.05,{ }^{\#} \mathrm{P}<0.01$ compared with normal control group; ${ }^{*} \mathrm{P}<0.05,{ }^{* *} \mathrm{P}$ $<0.01$ compared with model group. 


\section{Quercetin inhibits LPS-induced TLR2 mRNA overexpression in human PBMCs}

Then, we investigated the TLR2 mRNA levels by qRT-PCR followed by densitometry. Compared with the control group, TLR2 mRNA levels markedly increased in the model group $(\mathrm{P}<$ 0.01 ; Figure 3). However, quercetin treatment at all dosages $(25 \mu \mathrm{M}: \mathrm{P}<0.05 ; 50$ and $100 \mu \mathrm{M}: \mathrm{P}<$ 0.01 ) significantly reduced the LPS-induced increase in the expression of TLR2 mRNA in this model.

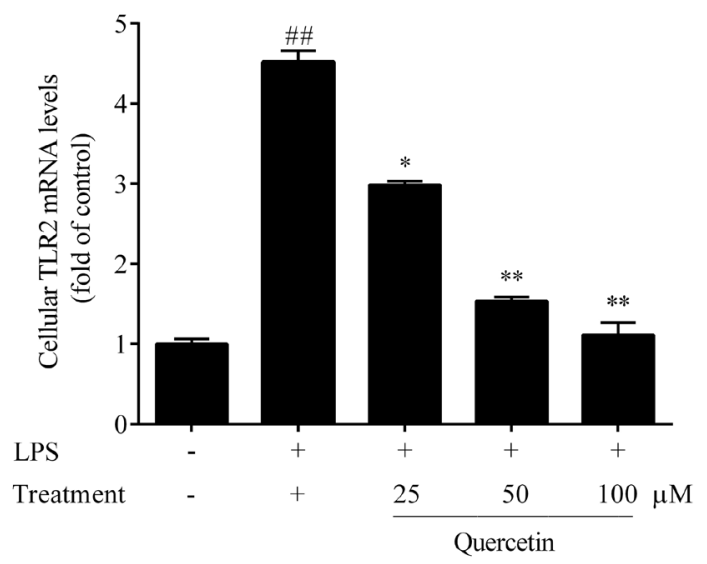

Figure 3. Effects of quercetin on the expression of TLR2 mRNA in LPS-stimulated human PBMCs. Data are reported as means $\pm \mathrm{SD}(\mathrm{N}=3)$. ${ }^{\#} \mathrm{P}<0.01$, compared with normal control group; ${ }^{*} \mathrm{P}<0.05,{ }^{*} \mathrm{P}<0.01$ compared with model group.

\section{Quercetin decreases NF-кB levels in LPS-stimulated human PBMCs}

We investigated whether quercetin affected NF- $\mathrm{kB}$ levels in LPS-stimulated human PBMCs. Figure 4 shows that $10 \mu \mathrm{g} / \mathrm{mL}$ LPS greatly increased NF- $\kappa B$ concentrations in human PBMCs $(\mathrm{P}<$ 0.01 ) compared with the normal control group. More importantly, 50 and $100 \mu \mathrm{M}$ quercetin significantly decreased NF- $\kappa B$ concentrations in LPS-stimulated human PBMCs $(\mathrm{P}<0.05)$.

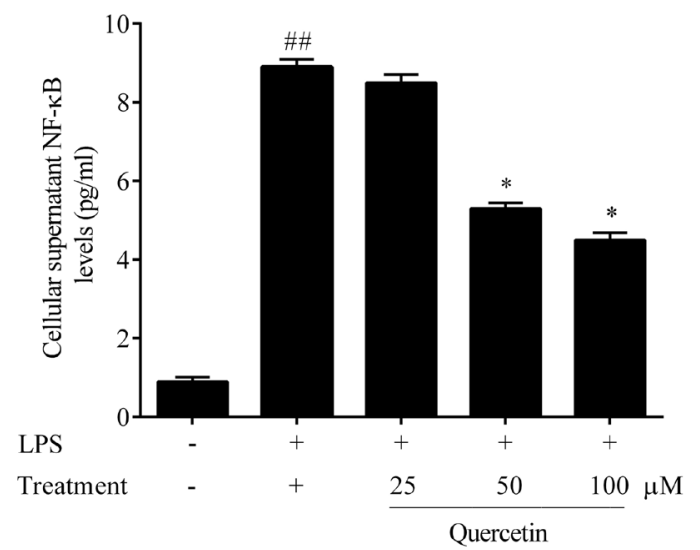

Figure 4. Effects of quercetin on NF- $\kappa B$ levels in LPS-stimulated human PBMCs. Data are shown as mean $\pm \mathrm{SD}$ $(\mathrm{N}=3) .{ }^{\#} \mathrm{P}<0.01$ compared with normal control group; $* \mathrm{P}<0.05$ compared with model group. 


\section{DISCUSSION}

Over-reaction to LPS has been implicated in clinical conditions such as septic shock, inflammatory bowel disease, ARDS, and other local or systemic inflammatory disorders (De Saedeleer et al., 1991). Quercetin, as a flavonoid molecule ubiquitous in nature, was reported to ameliorate LPS-induced systemic inflammation in mice (Liao and Lin, 2015) and suppress inflammation in LPS-induced acute lung injury in rats (Huang et al., 2015). Cytokines, secreted from monocytes and other activated immune cells, play an important role in the regulation of inflammatory responses induced by LPS. TNF- $\alpha$, IL-1 $\beta$, and IL-6, major pro-inflammatory cytokines, are involved in the pathogenesis of inflammatory diseases. A previous study reported that quercetin administration markedly decreased the production of TNF- $\alpha$, IL-1 $\beta$, and IL-6 in bronchoalveolar lavage fluid cells activated by LPS (Takashima et al., 2014). Moreover, quercetin could inhibit TNF- $\alpha$ gene expression in normal human PBMCs via modulating the NF- $\kappa B$ pathway (Nair et al., 2006). In the present study, increased concentrations of TNF- $\alpha$, IL-1 $\beta$, and IL-6 were observed in LPS-stimulated human PBMCs. Quercetin was found to decrease TNF- $\alpha$, IL-1 $\beta$, and IL-6 secretion in this model. The results suggest that quercetin has the ability to ameliorate LPS-induced inflammation in human PBMCs.

It is clear that TLRs play a critical role in LPS-induced inflammation (Akira et al., 2001). TLR family members are expressed differentially among immune cells, and TLR2 is expressed in human monocytic cell lines and human monocytes (Medzhitov et al., 1997). In the present study, we found that the mRNA expression of TLR2 was significantly elevated in LPS-stimulated human PBMCs in comparison to the normal control group, which suggests that TLR2 signaling may play an important role in LPS-induced inflammation in human PBMCs. Treatment with quercetin resulted in significant inhibition of the mRNA expression of TLR2 in LPS-stimulated human PBMCs.

Activated TLRs trigger the downstream stimulation of NF- $\mathrm{BB}$, thereby reducing the activation of key inflammatory mediators (May and Ghosh, 1998; Sabroe et al., 2008). NF-кB, a nuclear transcription factor, is a regulator of inflammatory processes (Jeong et al., 2014). Previous studies demonstrated that treatment with quercetin inhibits LPS-induced NF-кB activation in RAW 264.7 macrophages (Cho et al., 2003). In the present study, LPS greatly increased NF- $\mathrm{KB}$ concentrations in human PBMCs compared with the normal control group. The treatment with quercetin significantly decreased the elevated concentration of NF- $\mathrm{KB}$ in LPS-stimulated human PBMCs. The results suggest that quercetin suppresses LPS-induced inflammatory responses possibly via inhibiting the TLR2/NF- $\mathrm{B}$ signaling pathway activation in human PBMCs. However, further investigation is also needed to clarify the precise mechanism by which quercetin inhibits over-expression of TLR2.

In summary, we provide evidence to show that treatment with quercetin has potent protective effects against LPS-induced inflammation in human PBMCs via suppression of LPS-induced TLR2/NF- $\mathrm{BB}$ signaling pathway activation. Therefore, the present study may provide an experimental basis for further clinical applications of quercetin for the treatment of inflammatory diseases due to over-reactive inflammatory response. However, further investigation is also needed to clarify the precise mechanism by which quercetin inhibits the over expression of TLR2.

\section{Conflicts of interest}

The authors declare no conflict of interest. 


\title{
ACKNOWLEDGMENTS
}

\author{
Research supported by the Dongguan Soft Science Project (grant \#DK10016).
}

\section{REFERENCES}

Ahn J, Lee H, Kim S, Park J, et al. (2008). The anti-obesity effect of quercetin is mediated by the AMPK and MAPK signaling pathways. Biochem. Biophys. Res. Commun. 373: 545-549. http://dx.doi.org/10.1016/j.bbrc.2008.06.077

Akira S (2006). TLR signaling. In: From innate immunity to immunological memory. Springer, 1-16.

Akira S, Takeda K and Kaisho T (2001). Toll-like receptors: critical proteins linking innate and acquired immunity. Nat. Immunol. 2: 675-680. http://dx.doi.org/10.1038/90609

Angeloni C and Hrelia S (2012). Quercetin reduces inflammatory responses in LPS-stimulated cardiomyoblasts. Oxid. Med. Cell Longev. Article ID 837104, 8 pages.

Cho SY, Park SJ, Kwon MJ, Jeong TS, et al. (2003). Quercetin suppresses proinflammatory cytokines production through MAP kinases andNF-kappaB pathway in lipopolysaccharide-stimulated macrophage. Mol. Cell. Biochem. 243: 153160. http://dx.doi.org/10.1023/A:1021624520740

Cohen J (2002). The immunopathogenesis of sepsis. Nature 420: 885-891. http://dx.doi.org/10.1038/nature01326

De Saedeleer V, Wechsung E and Houvenaghel A (1991). Endotoxin in the conscious piglet: its effects on some general and gastrointestinal myoelectrical parameters. Vet. Res. Commun. 15: 227-238. http://dx.doi.org/10.1007/BF00343227

Dijkstra D, Leurs R, Chazot P, Shenton FC, et al. (2007). Histamine downregulates monocyte CCL2 production through the histamine H4 receptor. J. Allergy Clin. Immunol. 120: 300-307. http://dx.doi.org/10.1016/j.jaci.2007.03.024

Gomes IB, Porto ML, Santos MC, Campagnaro BP, et al. (2014). Renoprotective, anti-oxidative and anti-apoptotic effects of oral low-dose quercetin in the C57BL/6J model of diabetic nephropathy. Lipids Health Dis. 13: 184. http://dx.doi. org/10.1186/1476-511X-13-184

Guha M and Mackman N (2001). LPS induction of gene expression in human monocytes. Cell. Signal. 13: 85-94. http:// dx.doi.org/10.1016/S0898-6568(00)00149-2

Huang R, Zhong T and Wu H (2015). Quercetin protects against lipopolysaccharide-induced acute lung injury in rats through suppression of inflammation and oxidative stress. Arch. Med. Sci. 11: 427-432. http://dx.doi.org/10.5114/ aoms.2015.50975

Jenny M, Klieber M, Zaknun D, Schroecksnadel S, et al. (2011). In vitro testing for anti-inflammatory properties of compounds employing peripheral blood mononuclear cells freshly isolated from healthy donors. Inflamm. Res. 60: 127-135. http://dx.doi.org/10.1007/s00011-010-0244-y

Jeong JW, Lee HH, Han MH, Kim GY, et al. (2014). Anti-inflammatory effects of genistein via suppression of the toll-like receptor 4-mediated signaling pathway in lipopolysaccharide-stimulated BV2 microglia. Chem. Biol. Interact. 212: 30-39. http://dx.doi.org/10.1016/j.cbi.2014.01.012

Jiang D, Liang J, Fan J, Yu S, et al. (2005). Regulation of lung injury and repair by Toll-like receptors and hyaluronan. Nat. Med. 11: 1173-1179. http://dx.doi.org/10.1038/nm1315

Li Y, Xiong W, Yang J, Zhong J, et al. (2015). Attenuation of inflammation by emodin in lipopolysaccharide-induced acute kidney injury via inhibition of Toll-like receptor 2 signal pathway. Iran. J. Kidney Dis. 9: 202-208.

Liao YR and Lin JY (2015). Quercetin intraperitoneal administration ameliorates lipopolysaccharide-induced systemic inflammation in mice. Life Sci. 137: 89-97. http://dx.doi.org/10.1016/j.lfs.2015.07.015

May MJ and Ghosh S (1998). Signal transduction through NF-k B. Immunol. Today 19: 80-88. http://dx.doi.org/10.1016/ $\underline{\text { S0167-5699(97)01197-3 }}$

Medzhitov R, Preston-Hurlburt P and Janeway CA, Jr. (1997). A human homologue of the Drosophila Toll protein signals activation of adaptive immunity. Nature 388: 394-397. http://dx.doi.org/10.1038/41131

Min YD, Choi CH, Bark H, Son HY, et al. (2007). Quercetin inhibits expression of inflammatory cytokines through attenuation of NF-kappaB and p38 MAPK in HMC-1 human mast cell line. Inflamm. Res. 56: 210-215. http://dx.doi. org/10.1007/s00011-007-6172-9

Morikawa K, Nonaka M, Narahara M, Torii I, et al. (2003). Inhibitory effect of quercetin on carrageenan-induced inflammation in rats. Life Sci. 74: 709-721. http://dx.doi.org/10.1016/j.1fs.2003.06.036

Nair MP, Mahajan S, Reynolds JL, Aalinkeel R, et al. (2006). The flavonoid quercetin inhibits proinflammatory cytokine (tumor necrosis factor alpha) gene expression in normal peripheral blood mononuclear cells via modulation of the NF-k b system. Clin. Vaccine Immunol. 13: 319-328. http://dx.doi.org/10.1128/CVI.13.3.319-328.2006

Pestka J and Zhou HR (2006). Toll-like receptor priming sensitizes macrophages to proinflammatory cytokine gene 
induction by deoxynivalenol and other toxicants. Toxicol. Sci. 92: 445-455. http://dx.doi.org/10.1093/toxsci/kfl012

Sabroe I, Parker LC, Dower SK and Whyte MK (2008). The role of TLR activation in inflammation. J. Pathol. 214: 126135. http://dx.doi.org/10.1002/path.2264

Strober W, Fuss I and Mannon P (2007). The fundamental basis of inflammatory bowel disease. J. Clin. Invest. 117: 514521. http://dx.doi.org/10.1172/JCI30587

Takashima K, Matsushima M, Hashimoto K, Nose H, et al. (2014). Protective effects of intratracheally administered quercetin on lipopolysaccharide-induced acute lung injury. Respir. Res. 15: 150. http://dx.doi.org/10.1186/s12931$\underline{014-0150-\mathrm{x}}$

Tianzhu Z and Shumin W (2015). Esculin inhibits the inflammation of LPS-induced acute lung injury in mice via regulation of TLR/NF-kappaB pathways. Inflammation 38: 1529-1536. http://dx.doi.org/10.1007/s10753-015-0127-Z

Vessal M, Hemmati M and Vasei M (2003). Antidiabetic effects of quercetin in streptozocin-induced diabetic rats. Comp. Biochem. Physiol. C Toxicol. Pharmacol. 135C: 357-364.

Werts C, Tapping RI, Mathison JC, Chuang TH, et al. (2001). Leptospiral lipopolysaccharide activates cells through a TLR2-dependent mechanism. Nat. Immunol. 2: 346-352. http://dx.doi.org/10.1038/86354

Yang T, Kong B, Gu JW, Kuang YQ, et al. (2014). Anti-apoptotic and anti-oxidative roles of quercetin after traumatic brain injury. Cell. Mol. Neurobiol. 34: 797-804. http://dx.doi.org/10.1007/s10571-014-0070-9

Yu PX, Zhou QJ, Zhu WW, Wu YH, et al. (2013). Effects of quercetin on LPS-induced disseminated intravascular coagulation (DIC) in rabbits. Thromb. Res. 131: e270-e273. http://dx.doi.org/10.1016/j.thromres.2013.03.002

Zhu JP, Wu K, Li JY, Guan Y, et al. (2016). Cryptoporus volvatus polysaccharides attenuate LPS-induced expression of pro-inflammatory factors via the TLR2 signaling pathway in human alveolar epithelial cells. Pharm. Biol. 54: $347-$ 353. http://dx.doi.org/10.3109/13880209.2015.1042981 